\title{
Don Quijote on the Plains: Harnessing Enthusiasm for the Quijote at the Undergraduate Level
}

\author{
Patricia W. Manning \\ The University of Kansas
}

\begin{abstract}
Teaching Miguel de Cervantes's El ingenioso hidalgo don Quijote de la Mancha in the undergraduate classroom can pose a myriad of linguistic and contextual challenges for students distanced from the text by the space of four hundred years. This paper details teaching strategies that incorporate linguistic activities, film, references to visual culture, and discussion to encourage deep learning on the part of undergraduate readers of Cervantes's classic novel.
\end{abstract}

Key Words: Pedagogy, Don Quijote, multimedia, Cervantes (Miguel de), active learning, illustrations, deep learning, images

$\mathrm{t}$ times, when the light bounces off the wind turbines near Montezuma, Kansas at just the
right angle, they almost resemble the traditional windmills one sees in Spain. But apart
from this climatological predisposition toward wind-power, other parallels between the plains of twenty-first-century Kansas and the seventeenth-century Spain of the Quijote are few and far between. Despite the large temporal and spatial gap between these two worlds, I am pleased to note the number of students in the upper-level literature course I teach on the Quijote who say that they have heard so much about El ingenioso hidalgo don Quijote de la Mancha that they are looking forward to reading the classic novel. ${ }^{1}$

Once we delve into the text, however, their enthusiasm often flags. When I look back on my own first encounter with the Quijote, I realize that knowledge of the frameworks of the English novelistic tradition and the quest narrative helped me in my own first reading of the text. My students, on the other hand, often find these examples as inscrutable as the seventeenth-century Spanish before them. Although my experiences are based upon teaching an upper-level literature course in Spanish at a large state university, I believe that the challenges these new readers of the Quijote confront are shared by many undergraduate students. ${ }^{2}$ Students at the University of Kansas, like many current college students, are often double or even triple majors. Since most majors plan to use their Spanish in a professional context, their elective coursework is focused on academic field(s) other than literature. While Spanish majors have obtained a formation in literary analysis during their coursework, most of these experiences focus on the contemporary period and are thus not of great aid in understanding the Spain depicted in Cervantes's masterpiece.

As will be evident in the course of this article, my teaching of the Quijote has been profoundly influenced by the essays in the 1984 MLA collection Approaches to Teaching Cervantes' [sic] Don Quixote, especially Ruth El Saffar's exhortation to "find our students' equivalents of Don Quixote's romances of chivalry" (54) and Edward H. Friedman's "multiperspectivist" approach to the novel (87). As we celebrate the four-hundredth anniversary of the publication of Part One of El ingenioso hidalgo don Quijote de la Mancha, this essay seeks to bring the teaching of the Quijote into the Twenty-First Century by detailing a multimedia-based pedagogical approach to the novel. ${ }^{3}$ My paper will share the strategies I employ to address the three principal challenges I have found in teaching the Quijote to undergraduates: the negotiation of linguistic difficulties in what is often students' first experience with Spanish that is not contemporary, the contextualization of the text in a manner that resonates with learners of the digital generation through cinematic

"Don Quijote on the Plains: Harnessing Enthusiasm for the Quijote at the Undergraduate Level"

Hispania 88.1 (2005): 64-71 
example, and the encouragement of individual interpretation of the Quijote through analysis of illustrations of the novel.

\section{Pedagogical Approaches}

My approach to teaching in general, and to the Quijote in particular, is informed by J. B. Biggs's definition of the three types of learning: surface, achieving, and deep. Surface learning involves the memorization of discrete, isolated parcels of information in order to pass the course. Students practicing achieving learning are motivated by grades; they want to earn the highest grade they can. Deep learning, however, encourages students to acquire a personal understanding of the course material. A key factor in achieving a profound understanding of course content is the internalization of key concepts. In order for these ideas to be internalized, learners must process them, rather than simply hearing them delivered in a lecture (Herrin 3). Therefore, I employ a variety of active learning strategies, such as in-class analytical tasks and group work, to facilitate learners' engagement with the subject matter at hand. ${ }^{4}$ Rather than promulgate a particular interpretation of Cervantes's novel, my goal is to move students who sign up for the course to fulfill a requirement past the achieving or surface learning stages toward a deeper understanding of the subject matter.

The interpretation of visual imagery plays a vital role in this strategy by presenting an unfamiliar time period in a context readily comprehensible to students accustomed to the slick visuals of television and video games. While the incorporation of images into classroom activities indubitably appeals to visual learners, and, as Gwen H. Stickney indicates, clarifies the content of reading for students and demonstrates the popularity of the novel (4), illustrations can serve a far more profound role in the interpretation of the text. While some may consider illustrations as mere adornments of the written word, theories of visual culture analyze images as significant cultural products. ${ }^{5}$ As Rachel Schmidt's Critical Images: The Canonization of Don Quixote through Illustrated Editions of the Eighteenth Century compellingly demonstrates, illustrations of the Quijote are critical interpretations of the novel in their own right (12-13). Moreover, images of the Quijote proved so popular that many of them took on a life of their own, circulating apart from the novel (Schmidt 11-12), as in the collection by George Cruikshank and the compilation of the works of various engravers entitled Les principales avantures [sic] de I'admirable Don Quichotte [...]. Thanks to the abundance of illustrated editions of the Quijote in the Spencer Research Library at the University of Kansas, my students have the opportunity to view many of the images I mention in person; however, 1 cite published reproductions of these illustrations whenever possible in this article. In addition, the MLA collection on Approaches to Teaching Cervantes' [sic] Don Quixote lists a variety of visual material relating to the Quijote (Bjornson 180-81). My Appendix also lists images available in electronic media disseminated since the publication of the MLA collection.

For the reader who may worry that this emphasis on multimedia will take class time away from the study of the text of the Quijote itself, I cite the response of Judith Logan, one of the teachers considered in the American Association of University Women's study on girls' selfesteem, to a similar query: "Well, if you start a course on women's history with sexual harassment, with something that connects to the students' experience, you'll get to Susan B. Anthony eventually. And it will mean more to them, because they can relate it to their own experience. But if you start with Susan B. Anthony, you may never get to sexual harassment, and you lose that important connection to their lives" (Orenstein 265). In incorporating multimedia, not only does my class have plenty of time to dedicate to the Quijote, but students also interact more fruitfully with the text as a result of these comparisons to contemporary life.

\section{Setting the Scene}

It seems there is always one student in every course who, despite frequent exhortations to 
deduce the meaning of unknown words from context, insists on looking up and annotating every new term. While such a task proves daunting in any setting, it proves Herculean and frustratingly futile for the reader of the Quijote who searches modern dictionaries for archaic terminology. In teaching lower-level language courses, most of us likely have a favorite activity in our teaching repertoire to encourage judicious dictionary usage. My personal favorite involves removing every fourth word from a text and replacing the missing word with a corresponding number of $\mathrm{x}$ 's. This activity helps to demonstrate to students how much of a text they can comprehend from context and how to determine which missing words are essential to their comprehension of the novel. My students work on the following activity at the beginning of the semester:

En un lugar de XX Mancha, de cuyo nombre no XXXXXX acordarme, no ha mucho XXXXXX que vivia un hidalgo XX los de lanza en XXXXXXXXX, adarga antigua, rocin flaco $\mathrm{X}$ galgo corredor. Una olla $\mathrm{XX}$ algo m\&s vaca que $\mathrm{XXXXXXX}$, salpicon las mas noches, XXXXXX y quebrantos los sabados, XXXXXXXX los viernes, algun palomino XX afiadidura los domingos, consumian XXX tres partes de su XXXXXXXX. El resto della concluian XXXX de velarte, calzas de XXXXXXX para las fiestas, con XXX pantuflos de lo mesmo, $\mathrm{X}$ los dias de entre XXXXXX se honraba con su XXXXXXX de lo m\&s fino. (I, $1 ; 21)^{6}$

1. £Quín narra este trozo de la novela?

2. Favor de describir la situaci6n econ6mica en que se encuentra el hidalgo.

3. iQu6 tipo de calzas tiene el hidalgo para las fiestas?

4. Favor de buscar la palabra "vellori" en un diccionario moderno y en el diccionario del profesor Lathrop.

The discussion of these questions simultaneously emphasizes the need for careful close reading and the amount of information that can be deduced from context. For example, the meticulous reader, even without the missing verb quiero, will notice the first-person pronoun attached to the infinitive \{acordarme) and determine that a first-person narrator narrates the passage. Despite the missing term velludo, students generally determine that Don Quixote's clothing for feast days would likely be more luxurious than his everyday attire. Therefore, velludo is not essential to their comprehension of the text. Later in the semester, once students have become accustomed to Cervantes's employment of refranes, we return to this passage. During this second reading, students also use the refranes Sebasti\&n de Covarrubias incorporates into his definitions of carnero and vaca in Tesoro de la lengua caste liana o espanola (309) to analyze the passage in more detail.

The management of archaic language is not the only linguistic challenge that confronts these learners. At some point in our lives, we all have found ourselves in the awkward position of explaining a joke to someone who does not understand why it is funny; in the end, the laborious process of explaining the joke makes the moment of epiphany a great disappointment. The same phenomenon occurs in explanations of the humorous wordplay that punctuates Sancho's speech. Indeed, although the explanatory notes accompanying the text help students understand the linguistic play, the humor still eludes them. In order to convey this wit to students, I turn to a passage in Kathy Acker's 1986 pastiche novel, Don Quixote, in which the wordplay duplicates the type of linguistic confusion often evident in Sancho's language: "He whom I love is my eyes and heart and I'm sick when I'm not with him, but he doesn't love me. He's my eyes; he's my I's; I see by my I's; he's my sun. My son lets me see and be [...]. I'll say it again: without I's, the I is nothing" (101). As a result of this comparison, learners better comprehend the humor inherent in Sancho's linguistic confusions.

\section{Chivalric Cinema}

Once students overcome their initial linguistic discombobulation, we turn to the thematics of 
the ballads, romances, and chivalric tales upon which Quixote's initial adventures are based. As these tales are largely unfamiliar to students, they are befuddled by the aged knight's firm belief in the powers of magicians to transform giants into windmills or spirit away his library, as well as his undying faith in the curative powers of his balsamo. When I first encountered this gap in my class's literary background, my initial impulse was to give a brief lecture to the group on the characteristics of Arthurian legends and the chivalric tradition. This strategy, however, only emphasized what students did not know and succeeded in alienating them from the text. When we attempted to return to our discussion, the group, acutely aware of how much contextual information they were missing, no longer wished to offer their opinions.

In order to contextualize these motifs in a more accessible fashion, I now choose to present them through the cinematic example of Ron Howard's film Willow. By showing the DVD with the Spanish language audio track, this contextualization does not require abandoning the target language. While the now classic comparison between Star Wars and Cervantes's fiction resonates with me personally, references to Star Wars have never worked well for my classes. My twentysomething students, many of whom were not yet born when the film was first released in 1977, seem only to notice that the special effects are now hopelessly outdated. They entirely miss the archetypal myths that underpin the movie. They also find it difficult, if not impossible, to connect Star Wars' futuristic setting with the seventeenth-century Spain of Cervantes's novel. In order to inform their screening of Willow, I give students a series of questions to consider when viewing the film:

1. ${ }^{\wedge}$ De que manera se manifiesta la batalla entre el bien y el mal en la pelicula?

2. ${ }^{\wedge} \mathrm{Ve}$ Ud. algunas connotaciones religiosas en la huida de Elora Danan del reino de

Bavmorda?

3. Favor de describir la relacion entre los dos viajeros-Willow y Madmartigan.

4. ^ Cual es el papel de la magia a lo largo de la pelicula?

5. Favor de notar las instancias en las que los personajes emplean encantos u otras formas de magia.

6. ^En qu6 consiste el objetivo de la busqueda de Willow?

Using these questions as a springboard for discussing the film, students come away with a better understanding of the chivalric elements that Quixote and Sancho's quest parodies. Moreover, the inclusion of Willow as part of the course emphasizes the striking absence of female figures in Don Quixote's chivalric world. This observation sets the scene for our later readings of psychological interpretations of Alonso Quijano.

\section{Image and Interpretation}

During the initial weeks of the semester, students frequently work in small groups to analyze illustrations of the novel and their critical implications. One group works with C61estin Nanteuil's chromolithograph (El ingenioso 1855 ed. opposite page 3), which portrays a disheveled Don Quixote sitting in his book-filled study, his shirt open to mid-chest and an unkempt white fringe of hair surrounding his bald pate. With one book propped open and sitting on top of others, he holds a battered sword aloft in his left hand. Rather than contemplate the text before him, his wild eyes stare off the page to make eye contact with the reader. Like its occupant, the room in which he sits is in disarray: books are piled high on the desk and are strewn on the floor along with the scattered pieces of an aged suit of armor. Meanwhile, another group works with a starkly different representation of Quixote poring over libros de caballerias in his study: John Vanderbank's Alonso Quijano (Schmidt 84, figure 22). This hidalgo also holds a book open before him, but he occupies a precisely ordered study. Rather than make eye contact with the reader, however, the neatly turned-out, dark haired hidalgo contemplates, almost too intently, the breastplate on the wall opposite his desk. 
Each group of students uses the same questions to analyze these radically differing images of the hidalgo before he undertakes his quest to restore knight-errantry:

1. Favor de describir el estado (fisico, de dnimo) de este hidalgo. ^Parece cuerdo?

2. i,Se establece contacto visual entre el lector y don Quijote? Si don Quijote le mira al lector, rque es el impacto de esta mirada?

3. Segun lo que se puede deducir de esta imagen, ^por que sale este don Quijote de su casa?

When the class reconvenes in a large group, we discuss the differing impressions created by the images, juxtaposing the pathos evident in Nanteuil's representation of the crazy Don Quixote with Vanderbank's portrayal of the hidalgo as an English squire.

We do a similar analytical comparison of Picasso's famous rendering of Don Quixote and Sancho (Lo Re 106, figure 1) and Jos6 del Castillo's version of Sancho and his master on the road (Schmidt 16, figure 4). In Picasso's rendering, the tall, thin knight, carrying both lance and shield, and his portly squire stand atop a small rise underneath the full sun. Behind them, the landscape is blank except for four windmills. In del Castillo's version, however, both parties are portrayed in rich detail. Quixote, whose figure is slightly larger than that of his squire, wears a magnificent suit of armor. Sancho, gesturing with his hand over his heart, looks adoringly at his master. Using these images, the class again divides into groups and analyzes the images by answering the following questions:

1. ^Cu\&l es la figura m\&s importante de la imagen? ${ }^{\wedge}$,Por que?

2. A base de esta imagen, favor de describir la relaci6n entre Sancho y don Quijote.

3. Segun esta imagen, i,qu6 es el tema central de la obra?

4. £C6mo va a ser la novela (chistosa, llena de acci6n, seria, etcetera)?

When the class convenes again as a whole, we discuss whether the relationship between Sancho and Quixote, as Jos6 del Castillo's illustration seemingly implies, is the novel's central message, or whether the text portrays the existentialist alienation of one individual from another. We then discuss the implications of the classicizing elements of del Castillo's representation and how they are distinguishable from Picasso's possible source of inspiration in popular culture (Lo Re 107).

The depiction of one of the windmills as a giant in the center of Picasso's painting, visible between Rocinante's front and back legs, alludes to a key issue at the heart of the illustration tradition of the novel: the point of view from which the illustration is drawn. As most students already know something about Don Quixote's encounter with the windmills before they even read the novel, the study of these illustrations proves particularly fruitful. ${ }^{7}$ Salvador Dali's windmills $\{E l$ ingenioso ed. 1957, opposite 68) bear a startling resemblance to giants. Moreover, Dali's illustration gives the reader insight into Quixote's mental processes; the foreground of the image is a cut-away of Quixote's head in which the viewer clearly sees the image of a giant in the knight's mind. In contrast to this representation of Quixote's illusion, M. Pisan $\{$ El ingenioso ed. 2001 xliii) chooses to depict a later moment in the same adventure. Quixote and Rocinante both lie on their backs on the ground underneath the tattered sail of a windmill. Sancho, dragging his donkey behind him, approaches the prone man and nag. The class again discusses one of the illustrations in small groups with the following questions:

1. De acuerdo con la imagen, ^es comprensible el error de don Quijote?

2. Segun lo que ve, \&/,es el comportamiento de don Quijote heroico?

3. [,Qut es el impacto de representar este momenta particular de la aventura?

4. ^,Esta imagen le afecta emocionalmente? ${ }^{\wedge}$ Por que o por qu£ no?

After the small-group discussion, the class considers how the comprehensibility (or lack thereof) of the quixotic delusions affects readings of the novel. 
Through discussion of these illustrations, students are visually exposed to the major interpretative schools of Cervantes's text, such as classicizing, romantic, and humorous. This orientation facilitates reactions to critical articles later in the semester. Having analyzed images that embody key critical schools of thought, students are better prepared to deconstruct arguments. Finally, these illustrations emphasize the divergent perspectives on the novel.

Lest the focus on illustrations from other eras fossilize Cervantes's novel for students, we also examine contemporary interpretations of the Quijote during the course of the semester. For example, an ad campaign by Bassat, Ogilvy and Mather for Vedior-Laborman, a Spanish temporary job agency, features Don Quixote and Sancho. In the extreme right hand corner of the ad, a well-kempt Quixote, dressed in period costume with his basin-helmet, and holding a lance so immense its top is not visible, stares blankly off into space. Meanwhile, Sancho, hands on a wide belt that supports his ample panza, stands with his head turned toward his master. The tag line reads "buscamos a personas que se necesitan" and below it the Vedior-Laborman logo separates Quixote from Sancho. The text below the image asks the reader to: "Piense por un momento que seria El Quijote sin Sancho Panza o al reves. Nada. Uno necesita al otro. Es un claro ejemplo donde el exito depende de que las personas mas adecuadas se unan. Este es el trabajo que realiza Vedior-Laborman en Europa desde hace mas de 40 anos" (Vedior-Laborman). This photograph brilliantly introduces the interdependence implicit in Salvador de Madariaga's concept of the sanchificacion of Don Quixote and the quijotizacion of his squire. Moreover, the ad's text reinforces the polyvalent nature of language and its interpretation. Students invariably discuss whether the association of success, particularly commercial success, and the literary duo is meant to be ironic.

In the United States of the twenty-first century, no reading of a canonical text can be complete without acknowledging the implications of the literary canon itself. To highlight the debate over the universality of the experiences represented by literary classics, we study passages from Kathy Acker's highly experimental version of Don Quixote. Acker's pastiche novel, which students see early in the semester as an example of Sancho's humor, feminizes the quixotic quest. Rather than as an effect of too much reading, Acker's heroine, still named Don Quixote, begins her quest as a direct result of a gendered experience: she has an abortion. After a conversation with her side-kick, St. Simeon, in the hospital, this female Quixote sets out on a series of adventures to "right all wrongs" (14) in the United States in the 1980s. Despite the radically different motivation for the journey, Acker's Quixote interacts with a similarly wide cross-section of society. Most often, the class concludes that the quest archetype, in one form or another, is comprehensible to most cultures.

Cinematic history provides an interesting exemplum of the absence of a definitive interpretation of Cervantes's novel. The screening of clips of Louis Pepe and Keith Fulton's documentary, Lost in La Mancha, which includes a discussion of Orson Welles's failed attempt to reproduce the Quijote in celluloid, as well as interviews with director Terry Gilliam about his thus far unsuccessful film project entitled The Man Who Killed Don Quixote, reinforces the lack of a definitive interpretation of Cervantes's literary classic.

While this article has highlighted visual culture as a mode to encourage student interaction with a literary text, I would be remiss if I were not to address briefly some of the non-visual strategies I employ to cultivate students' interaction with the novel. As is evident in the discussion of images, my class frequently works in small groups. Although some students can readily deal with highly complex contemporary texts, many students doubt their interpretations of early modern texts because of their temporal distance from the material. Especially in the early part of the semester, a brief paired discussion of the plot of the day's reading allows students to confirm their readings of the text, and with this additional reassurance, they all share more readily with the entire class.

In order to help students prepare for in-class discussions, I circulate discussion questions in advance. These questions ensure that students comprehend the basic plot line and highlight key points for our discussion in class. To further encourage students' interaction with the text, every 
two to three weeks I incorporate a class period with no assigned reading into the syllabus. Students submit questions they would like to discuss in advance, and we dedicate the next class period to these issues. Not only does this format give students a participatory role in what would otherwise be a lecture, but it also encourages learners to pose more questions in class. In addition to this discussion in the classroom, students also respond to periodic questions in an electronic discussion board. While I do not consider this electronic forum a substitute for class participation, it does enable students who need slightly more time to formulate their thoughts to take a more active role in this form of discussion with their classmates. Moreover, this format compels learners to think about textual interpretation outside of the classroom.

In the course of the semester, classroom activities model the analytical skills I expect students to use in their papers and exams. To this end, we frequently perform close readings in class. As has been discussed in detail, I use images to facilitate students' interaction with criticism of the novel. In order to hone students' research skills prior to writing their final papers, learners research an episode of their choosing from the novel, present one article or book chapter to the class, and submit an annotated bibliography of three additional texts that they consulted in their research.

One may well ask how the effectiveness of these strategies might best be assessed. I would argue that the most compelling measure of their effectiveness is the quality of work that students produce in the course of the semester. Student papers demonstrate a deep level of interaction with the novel. They successfully integrate criticism into their papers rather than citing published opinions in lieu of developing their own arguments. The efficacy of our linguistic exercises is underlined by one student, who had become so thoroughly immersed in seventeenth-century Spanish that he asked a colleague whether we were reading the Quijote in the original or in a translation into modern Spanish. Finally, I am reasonably confident that my students personalize their learning of the Quijote. Even after final grades are submitted, and any lingering motivations for a higher grade have evaporated, students continue to tell me about the connections to Cervantes's text that they encounter in their quotidian lives.

\section{NOTES}

'I wish to thank Edward H. Friedman and James A. Parr for the opportunity to share my ideas on teaching the Quijote and their thoughtful comments about this piece. Its defects are, of course, my own. Also, I gratefully acknowledge the many conversations about teaching that I have had with my colleagues, especially Andrew P. Debicki and Isidro J. Rivera, which have enriched my teaching of Cervantes's text. I owe a deep debt of gratitude to Richard Clement and the rest of the staff at the Spencer Research Library, who happily indulge my love of images of the Quijote. Since my thinking about the Quyote did not begin on the plains, I acknowledge my coastal debts and thank my teachers of the Quijote, Frank Durand and Roberto Gonzalez Echevarria, for kindling my enthusiasm for the text. Finally, I wish to thank my students for their enthusiasm. Without their hard work, I would have very little indeed to say about teaching the Quijote.

HTiese strategies can be fruitfully applied to other pedagogical contexts at the college level, such as a unit on the Quijote in a Spanish culture course, analysis of a selection of the novel in a literary survey course, or a course on the Quijote in English translation. Advanced Placement literature courses at the high-school level could also incorporate these teaching techniques.

*Gwen H. Stickney's on-line article on teaching the molinos de viento episode mentions both Rachel Schmidt's book and the Vedior-Laborman advertisement that I will discuss in detail. Her article, however, focuses on a different aspect of technology: outside-of-class activities that use the internet.

${ }^{4}$ Charles C. Bonwell's book discusses active learning in more detail.

${ }^{5}$ W. J. T. Mitchell and Barbara Maria Stafford's works provide detailed arguments in favor of the study and significance of images.

-All citations from the Quijote come from Tom Lathrop's edition, since this is the edition with which I teach. My interest in visual culture motivates this choice of text. While no edition of the Quijote is ideal, the bilingual features of Lathrop's edition facilitate comprehension of the novel for native speakers of English by defining terminology in a readily accessible manner.

${ }^{7} \mathrm{H}$. Pisan's representation of Don Quixote's attack on the sheep \{El ingenioso ed. 2001 xliv) and Salvador Dali's illustration of the same scene $\{$ El ingenioso ed. 1957, opposite 124) provide a similar contrast in the representation of quixotic delusions. 


\section{Enthusiasm for the Quijote at the Undergraduate Level Appendix: Electronic Resources for Images of the Quijote}

Biblioteca Virtual Miguel de Cervantes Saavedra. Ed. Florencio Sevilla Arroyo. 17 May 2004. 26 August $2004<\mathrm{http}$ / /www.cervantesvirtual.com/bib_autor/Cervantes/>.

Cervantes Project-Proyecto Cervantes. Ed. Eduardo Urbina. Texas A\&M University, Universidad de Castilla-la Mancha and Santander Central Hispano. 24 August $2004<\mathrm{http}: / /$ www.csdl.tamu.edu/cervantes>.

Cervantes y el Humor. Fundacion General de la Universidad de Alcala. 26 August $2004<\mathrm{http}$ //www.fgua.es/Cervantes/ CervantHg.htm>.

Don Quijote de la Mancha. Centre International d'Etudes en Litterature de Jeunesse. 23 July $2004<$ http:// www.ricochet-jeunes.org/es/biblio/basel/donquichotte.htm>.

Don Quijote de la Mancha. Eds. Anne Mulgrew and Sayeed Choudhury. 19 February 1998. Milton S. Eisenhower Library, Johns Hopkins University. 26 August $2004<$ http://quixote.mse.jhu.edu/index-es.html>.

Don Quixote. 28 August 2004. <http://www.donquixote.com/index.html>.

Dr. Widger's Library of Illustrated Ebooks. Ed. David Widger. Copyright Project Gutenberg. 21 July $2004<$ http:// beryl, ils.unc.edu/ widger/illustl .htm>.

Gonzalez Echevarria, Roberto, ed. Miguel de Cervantes. CD-ROM. Woodbridge, CT: Primary Source Media, 1998.

H-Cervantes. Life, Times, and Work. Eds. Daniel Eisenberg, Fred Jehle and Matthew Wyszynski. H-Net. Matrix. Michigan State University. 28 August $2004<\mathrm{http}: / /$ www.h-net.org/ cervantes>.

Works of Miguel de Cervantes. Ed. Fred Jehle. 6 October 2003. Indiana University-Purdue University Fort Wayne. 26 August $2004<$ http://users.ipfw.edu/jehle/wcimages.htm>.

\section{WORKS CITED}

Acker, Kathy. Don Quixote. New York: Grove P, 1986.

Biggs, J. B. The Study Process Questionnaire: Manual. Hawthorn, Australia: Australian Council for Educational Research, 1987.

Bjornson, Richard, ed. Approaches to Teaching Cervantes' [sic] Don Quixote. New York: Modern Language Association, 1984.

Bonwell, Charles C. and James A. Eison. Active Learning: Creating Excitement in the Classroom. ASHE-ERIC Higher Education Report 1. Washington, DC: School of Education and Human Development, George Washington University, 1991.

Cervantes Saavedra, Miguel de. El ingenioso hidalgo don Quijote de la Mancha. Illus. C\&estin Nanteuil. 2 tomos. Madrid: Establecimiento tipogr\&fico de D. F. de P. Mellado, 1855.

-. El ingenioso hidalgo don Quijote de la Mancha. Illus. Salvador Dall. 2 tomos. Buenos Aires: Emec6, 1957.

-. El ingenioso hidalgo don Quijote de la Mancha. Ed. Tom Lathrop. $5^{\text {th }}$ printing. Newark, DE: Juan de la Cuesta, 2001.

Covarrubias, Sebastian de. Tesoro de la lengua castellana o espahola. Ed. Martin de Riquer. Barcelona: S. A. Horta, 1943.

Don Quixote Illustrated in Fifteen Designs. Illus. George Cruikshank. London: Charles Tilt, 1834.

El Saffar, Ruth. "Coughing in Ink and Literary Coffins." Bjornson, ed. 50-55.

Friedman, Edward H. "Don Quixote and the Act of Reading: A Multiperspectivist Approach." Bjornson, ed. 87-95.

Fulton, Keith and Louis Pepe, directors. Lost in La Mancha. 2002. DVD. Quixote Films Limited, New Video, 2003.

Herrin, Don. "Deep Learning": A Critical Thinking Resource. Family and Consumer Studies, the University of Utah. 21 July $2004<$ http://www.fcs.utah.edu/faculty/herrin/deep_learning.html>. 1-45.

Howard, Ron, director. Willow. Story George Lucas. 1988. DVD. Twentieth Century Fox, Lucas Films Limited, 2001. Lathrop, Tom, compiler. Don Quijote Dictionary. $2^{\text {nd }}$ ed. Newark, DE: Juan de la Cuesta, 2001.

Lo Re, A. G. "A Possible Source for Picasso's Drawing of Don Quixote." Cervantes: Bulletin of the Cervantes Society of America 12.1 (1992): 105-10.

Madariaga, Salvador de. Guia del lector del Quijote: Ensayopsicoldgico sobre el Quijote. Madrid: Espasa-Calpe, 1987. Mitchell, W. J. T. Picture Theory: Essays in Verbal and Visual Representation. Chicago: U of Chicago P, 1994.

Orenstein, Peggy. In association with the American Association of University Women. School Girls: Young Women, Self-Esteem, and the Confidence Gap. New York: Doubleday, 1994.

Les principales avantures [sic] de I'admirable Don Quichotte, representees en figures par Coypel, Picart le Romain, et autres habiles maitres avec les explications des XXXI planches de cette magnifique collection tiroes de Voriginal espagnol de Miguel de Cervantes. La Haie: Chez Pierre de Hondt, 1746.

Schmidt, Rachel. Critical Images: The Canonization of Don Quixote through Illustrated Editions of the Eighteenth Century. Montreal: McGill-Queen's UP, 1999.

Stafford, Barbara Maria. Good Looking: Essays on the Virtue of Images. Cambridge, MA: MIT P, 1996.

Stickney, Gwen H. "Ideas modernas para un texto antiguo: Nuevas aproximaciones a la ensefianza de la aventura de los molinos de viento en Don Quijote." 28 August 2004. <http://www.iupui.edu/ flac/Stickney.html>. 1-6.

Vedior-Laborman. Advertisement. ABC 3 May 1998. 